\title{
OPTIMIZATION OF EXTRACTION CONDITIONS OF SOME POLYPHENOLIC COMPOUNDS FROM PARSLEY LEAVES (PETROSELINUM CRISPUM)
}

\author{
Paula Kuźma ${ }^{凶}$, Beata Drużyńska, Mieczysław Obiedziński \\ Department of Biotechnology, Microbiology and Food Evaluation, Warsaw University of Life Sciences - SGGW \\ Nowoursynowska 159, 02-787 Warsaw, Poland
}

\begin{abstract}
Background. Parsley leaf is a rich source of natural antioxidants, which serve a lot of functions in human body and prevent food from oxidation processes. The aim of the study was to investigate the influence of different extraction solvents and times of extraction on natural antioxidants content. Owing to the knowledge of the properties of extracted components and solvents, as well as their interactions, it is possible to achieve a high effectiveness of active compounds recovery.

Material and methods. Three different extraction solvents (acetone $70 \%$ in water, methanol $80 \%$ in water and distilled water) and different times of extraction (30 and 60 minutes) were used to determine the efficiency of extraction of polyphenols and catechins, antioxidant activity against free radicals DPPH and ABTS and the ability to chelate ion $\mathrm{Fe}^{2+}$ in dried parsley leaves. Other natural antioxidants contents in parsley leaves were also determined.

Results and discussion. In this study the best extraction solvent for polyphenols was acetone $70 \%$ and for catechins was distilled water. All extracts examined displayed the antioxidative activity, but water was the best solvent in the method of assaying the activity against $\mathrm{ABTS}^{++}$and $\mathrm{Fe}^{2+}$ ions chelating capability, whereas methanol turned out to be the least effective in this respect. Opposite results were observed in the case of determining the activity against $\mathrm{DPPH}^{*}$. The prolongation of the extraction time enhanced or decreased antiradical activity in some cases. Additionally, important biologically active compounds in parsley leaves, such as vitamin C (248.31 mg/100 g dry matter), carotenoids (31.28 mg/100 g dry matter), chlorophyll (0.185 mg/g dry matter) were also analysed.
\end{abstract}

Key words: efficiency of extraction, antioxidant properties, natural antioxidants

\section{INTRODUCTION}

Natural antioxidants are significant food constituents and serve a number of functions in a human body. High contents of antioxidants may be found in fruits and vegetables as well as in their processed products. Their action is chiefly based on the neutralization of free radicals and on the prevention from oxidation processes [Sikora et al. 2008].
Polyphenols are chemical compounds being secondary plant metabolites. They constitute the most abundant group of natural antioxidants [Rosicka-Kaczmarek 2004].

Carotenoids are natural pigments, synthesized by higher plants, bacteria, algae and fungi [Mosiewicz 2002]. As antioxidants, they contribute to organism

凶paula_kuzma@sggw.pl 
defense against damages induced by the action of the reactive oxygen species [Szpetnar and Pasternak 2003].

Vitamin C occurs in two forms: as L-ascorbic acid and in the oxidized form as L-dehydroascorbic acid. Both these forms display the same vitamin activity. Vitamin $\mathrm{C}$ is an indispensable food constituent. It participates in, e.g., blood vessels tightening, it accelerates blood coagulation and yields detoxifying effects [Kleszczewska 2007].

In higher plants occur two types of chlorophyll: $a$ and $b$. Chlorophyll and its derivatives exert a positive effect on a human body by complexing selected chemical compounds claimed to be carcinogenic agents. They are additionally very strong antioxidants [Ferruzzi and Blakeslee 2007, Zeno 2007].

The most common method of isolating active compounds from a plant material is extraction with the use of a solvent. Its effectiveness depends on many factors, including: chemical composition of raw material, storage conditions, size and comminution degree of a sample, method and parameters of extraction, and the presence of interfering factors [Koffi et al. 2010]. The selection of extraction conditions is mainly based on the selection of solvent type, time and temperature of extraction [Gao and Liu 2005]. Owing to the knowledge of the properties of extracted compounds and solvents, as well as their interactions, it is possible to achieve a high effectiveness of components recovery. Polar solvents are frequently employed for the recovery of polyphenols from a plant matrix. The most common are organic solvents, such as methanol, acetone, ethanol and ethyl acetate. It may be caused by the fact that the higher molecular weight of the extractant is, the lower polarity is needed to allow the substances of similar molecular weight to be extracted easily. In addition, higher phenolic contents and antioxidant activity are obtained using aqueous organic solvents than the respective absolute organic solvents The researchers suggest that this is due to the polarity, because by increasing the proportion of more polar water to the solvent, the polarity of the mixture also increases. It is also suggested that the aqueous organic solvents are able to extract both high and low polarity compounds [Sultana et al. 2009, Uma et al. 2010]. Thus, aqueous methanol (80\%), aqueous acetone $(70 \%)$ and distilled water were chosen as the extractants for the determination the contents of polyphenols, catechins and antioxidant activity of parsley leaves in this study. Different times of extraction (30 min and $60 \mathrm{~min}$ ) were tested to check if the prolongation of the extraction time will result in an increased extraction effectiveness of polyphenolic compounds and will enhance antiradical activity.

\section{MATERIAL AND METHODS}

Plant material. The experimental material in this study were dried parsley leaves (Petroselinum crispum) available in retail trade in Polish market. During the test material was stored in a dry and dark place in the original packages. Before extraction samples were crushed in mortar to increase the contents of extracted compounds.

Chemicals. All reagents used in the study were of pure analytical grade, unless otherwise specified. Acetone, sulphuric acid (VI), crystalline vanillin, ethyl alcohol 96\%, iron chloride (II) 4-hydrate, Folin and Ciocalteu reagents, anhydrous sodium carbonate, potassium dichromate (VI), hexane, trisodium phosphate, potassium dihydrogen phosphate (purity $\geq 99 \%$ ), acetonitrile (appropriate for HPLC), and methanol (appropriate for HPLC) were from POCH S.A. (Gliwice, Poland). In turn, 2,2-diphenyl-1-picrylhydrazyl (DPPH'), 2,2-azino-bis-3-ethylbenzothiazoline-6-sulphonic acid $\left(\mathrm{ABTS}^{*+}\right),(-)$ epicatechin, ferrozine, gallic acid, anhydrous sodium sulphate, methaphosphoric acid, L-cysteine (purity $\geq 99 \%$ ), standard of L $(+$ ) ascorbic acid (purity $\geq 99.7 \%$ ), and potassium persulphate were from Sigma-Aldrich (Poznań, Poland).

Preparation of extracts. In order to determine the effect of two extraction periods (30 $\mathrm{min}$ and $60 \mathrm{~min}$ ) and three solvents $(70 \%$ aqueous solution of acetone, $80 \%$ aqueous solution of methanol and distilled water) on the contents of polyphenols and catechins and on the antioxidative properties of parsley leaves, 6 extractions were performed. Extracts were prepared by weighing on an analytical scale $15-\mathrm{g}$ portions of parsley leaves and addition of $150 \mathrm{ml}$ of the respective extractant to each portion. The extracts were shaken at a room temperature: for each extractant one extract was shaken for 30 minutes, whereas the other one for $60 \mathrm{~min}$. The extracts were filtrated to conical flasks with ground-in stopper and kept under cold store conditions without the access of light for maximally up to 4 weeks. 
Total polyphenolic content. The analysis was carried out with the Folin-Ciocalteu's method [Singleton and Rossi 1965]. $300 \mu 1$ of each extract was pipetted into different test tubes. To this solution $4.15 \mathrm{ml}$ of distilled water, $500 \mu \mathrm{l}$ of sodium carbonate solution $(20 \%)$ and $50 \mu \mathrm{l}$ of Folin-Ciocalteau were added. After 20 minutes the absorbance was measured at $700 \mathrm{~nm}$ using spectrophotometer Shimadzu UV-1201V. The total phenolic content was expressed as gallic acid equivalent through the calibration curve of gallic acid.

Total catechin content. The analysis was conducted according to the method by Swain and Hillis [1959]. To 4 tubes marked by the letters A, B, C and D were added respectively: A $-1 \mathrm{ml}$ of extract, $5 \mathrm{ml}$ of distilled water, $4 \mathrm{ml}$ of vanillin reagent ( $1 \mathrm{~g}$ of crystalline vanillin in $100 \mathrm{ml} 70 \% \mathrm{H}_{2} \mathrm{SO}_{4}$ ); $\mathrm{B}-1 \mathrm{ml}$ of extract, $5 \mathrm{ml}$ of distilled water, $4 \mathrm{ml}$ of $70 \% \mathrm{H}_{2} \mathrm{SO}_{4}$; $\mathrm{C}-1 \mathrm{ml}$ of suitable extractant (acetone $70 \%$, methanol $80 \%$, water), $5 \mathrm{ml}$ of distilled water, $4 \mathrm{ml}$ of vanillin reagent; D (blank) $-1 \mathrm{ml}$ of suitable extractant, $5 \mathrm{ml}$ of distilled water, $4 \mathrm{ml}$ of $70 \% \mathrm{H}_{2} \mathrm{SO}_{4}$. After 15 minutes, the absorbance of solutions was measured using a spectrophotometer Shimadzu UV-1201V at the wavelength $\lambda=520 \mathrm{~nm}$. The result $(R)$ was calculated according to the formula: $R=A-(B+C)$. The total catechin content was expressed as (-) epicatechin content through the calibration curve of (-) epicatechin.

DPPH radical scavenging assay. The analysis was carried out according to the method by Song et al. [1999]. The experimental sample was prepared by taking $4 \mathrm{ml}$ of the extract and and $1 \mathrm{ml}$ of DPPH' solution. The control sample was prepared by taking $4 \mathrm{ml}$ of suitable extraction solvent ( $70 \%$ acetone, $80 \%$ methanol or water) and $1 \mathrm{ml}$ of the $\mathrm{DPPH}^{*}$ solution. After $30 \mathrm{~min}$ the absorbance was measured using a spectrophotometer Shimadzu UV-1201V at a wavelength $\lambda=$ $517 \mathrm{~nm}$. Antioxidant activity was calculated according to the formula: $A=\left[\left(A_{c}-A_{s}\right) / A_{c}\right] \times 100 \%$, where: $A-$ antiradical activity, \%, $A_{c}$ - absorbance of the control sample, $A_{s}$ - absorbance of the experimental sample.

Free radical scavenging ability by the use of a stable ABTS radical cation. The analysis was conducted following the method by Re et al. [1999]. The experimental sample was prepared by taking $40 \mu \mathrm{l}$ of the extract and $4 \mathrm{ml}$ of the $\mathrm{ABTS}^{++}$solution. The control sample was prepared by taking $40 \mu \mathrm{l}$ of suitable extraction solvent $(70 \%$ acetone, $80 \%$ methanol or water) and $4 \mathrm{ml}$ of the $\mathrm{ABTS}^{++}$solution. After 6 minutes the absorbance was measured using a spectrophotometer Shimadzu UV-1201V at a wavelength $\lambda=734$ $\mathrm{nm}$. Antioxidant activity was calculated according to the formula: $A=\left[\left(A_{c}-A_{s}\right) / A_{c}\right] \times 100 \%$, where $A-$ antiradical activity, $\%, A_{c}-$ absorbance of the control sample, $A_{s}$ - absorbance of the experimental sample.

The ability to chelate iron ion. The analysis was carried out using iron chloride (II) and ferrozine [Lai et al. 2001]. Extracts and reagents were collected into tubes in appropriate order: $0.165 \mathrm{ml}$ of suitable extract and $2.335 \mathrm{ml}$ of suitable extractant and $0.250 \mathrm{ml}$ of $2 \mathrm{mM}$ solution of iron chloride (II). After 20 minutes $0.5 \mathrm{ml}$ of $5 \mathrm{mM}$ ferrozine solution was added to each tube. After another 10 minutes the absorbance of the solutions was measured using the spectrophotometer Shimadzu UV-1201V at a wavelength $\lambda=562 \mathrm{~nm}$. The percentage ability to chelate iron ions was determined through the calibration curve of iron chloride (II).

Determination of carotenoids content. The extraction and the analysis was carried out according to the method by Sztangret et al. [2001]. $0.250 \mathrm{~g}$ of dried parsley leaves were weighted. Next about $1.5 \mathrm{~g}$ of anhydrous $\mathrm{Na}_{2} \mathrm{SO}_{4}$ was added and the whole sample was mixed. The mixture was transferred into the flask and $25 \mathrm{ml}$ of hexane was added. Then the flask was shaken on a shaker at room temperature for $24 \mathrm{~h}$. After that, $2 \mathrm{ml}$ of carotenoid extract and $8 \mathrm{ml}$ of hexane were added into test tube. Next the absorbance was measured at $450 \mathrm{~nm}$ using spectrophotometer Shimadzu UV-1201V. The total carotenoid content was was determined through the calibration curve ( $180 \mathrm{mg}$ of potassium dichromate (VI) in $500 \mathrm{ml}$ of distilled water. $1 \mathrm{ml}$ of that solution is an equivalent of $2.05 \mu \mathrm{g}$ of $\beta$-carotene).

Vitamin C content by HPLC. $2 \mathrm{~g}$ of parsley leaves were weighed on an analytical scale. Next, $80 \mathrm{ml}$ of methaphosphoric acid solution with a concentration of $20 \mathrm{~g} / \mathrm{l}$ were added and the whole sample was mixed. It was then filled up with methaphosphoric acid, the flask was wrapped in aluminum foil and shaken for $30 \mathrm{~min}$ at a room temperature. Afterwards, the sample was filtrated to a conical flask. The analysis was carried out on an analytical column Discovery C8 (150 mm $\times$ $4.6 \mathrm{~mm} \times 5 \mu \mathrm{m})$ in a reversed phase system. The mobile phase was gradient. The flow rate was $0.4 \mathrm{ml} / \mathrm{min}$, 
whereas the injected volume was $10 \mu 1$. Detection was conducted with an UV detector at $\lambda=265 \mathrm{~nm}[\mathrm{PN}-\mathrm{EN}$ 14130:2004]. The time of retention was $6.148 \mathrm{~min}$.

Determination of chlorophyll a and $b$ content. The extraction and the analysis was conducted according to the method by Dżugan [2006]. $0.250 \mathrm{~g}$ of dried parsley leaves were weighted and transferred cylinder with a stopper. Then $10 \mathrm{ml}$ of methanol were added and the suspension was shaken thoroughly. After that the suspension was left fot 15 min in dark place to separate the phases. Then, $5 \mathrm{ml}$ of the upper layer was collected and filtered through filter paper wetted with methanol. To determine the contents of chlorophyll a and chlorophyll b, $1 \mathrm{ml}$ of extract and $6 \mathrm{ml}$ of methanol were added to the tube. Next the absorbance of the solution was measured using a spectrophotometer Shimadzu UV-1201V at two different wavelengths $\lambda_{1}=663 \mathrm{~nm}$ and $\lambda_{2}=645 \mathrm{~nm}$. The total chlorophyll content of chlorophyll [C] was calculated according to the formula: $C=8.02 \times A_{(663)}+20.2 \times$ $A_{(645)}, \mathrm{mg} / \mathrm{l}$, where $A_{(663)}-$ absorbance at a wavelength of $\lambda=663 \mathrm{~nm} ; A_{(645)}-$ absorbance at a wavelength of $\lambda=645 \mathrm{~nm}$. The content of chlorophyll a $C c h l_{(\mathrm{a})}$ and chlorophyll b $C c h l_{(\mathrm{b}}, \mathrm{mg} / \mathrm{l}$, was calculated according to the formulas: $C c h l_{(\mathrm{a})}=12.7 \times A_{(663)}-2.69 \times A_{(645)}$ and $C c h l_{(\mathrm{b})}=22.9 \times A_{(645)}-4.68 \times A_{(663)}$.

\section{Statistical analysis}

All assays were performed in at least 3 replications. Mean values and standard deviations were calculated using Microsoft Office Excel 2002. The statistical analysis of the two-factor experiment (ANOVA) examining the effect of two factors (factor A: extraction period occurring at two levels of variability, factor B: type of solvent occurring at three levels of variability) on the effectiveness of polyphenols extractions at a significance level of $\alpha=0.05$ and the Pearson correlation coefficients were carried out with STATGRAPHICS Plus 4.1 software.

\section{RESULTS AND DISCUSSION}

\section{Determination of total polyphenols}

The results showed that the polyphenol content ranges from 362.93 to $723.58 \mathrm{mg} / 100 \mathrm{~g}$ dry mass (d.m.) depending on the nature of the solvent and time of extraction. Out of the solvents examined, the highest effectiveness of polyphenolic compounds extraction was reported for the $70 \%$ acetone solution and the lowest for the $80 \%$ methanolic solution (Fig. 1).

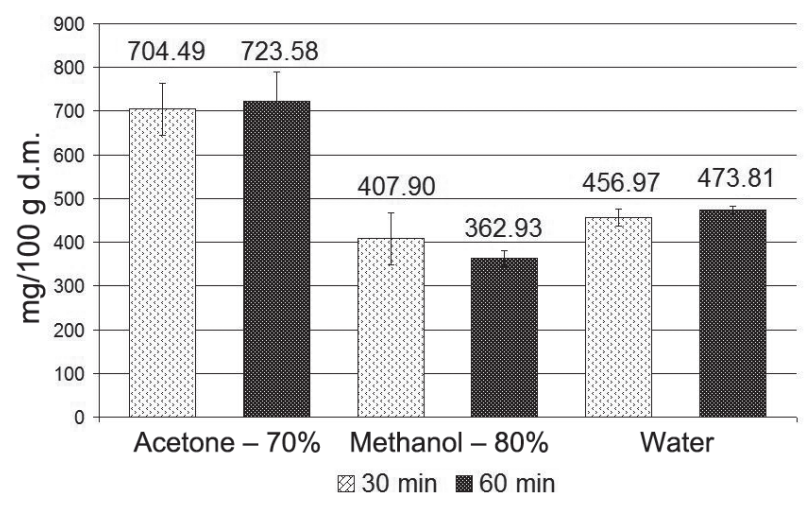

Fig. 1. Total polyphenolic content

The statistical analysis for two-factor experiment demonstrated significant effect of the extracting solution on polyphenols content in the extract. However, there is no important influence of the extraction time or no interaction between two factors.

According to literature data, the mean content of polyphenols in raw parsley leaves accounts for 1190 mg/100 g d.m. [Al-Mamary 2002]. The highest result obtained in the reported experiment was achieved after 60-minute extraction with acetone.

Rząca and Witrowa-Rajchert [2009] report that the content of polyphenols in dried material is affected by the method of the drying process and that may be the reason of extracting smaller amounts of polyphenols. In turn, Dragovic-Uzelac et al. [2005] emphasize that the total polyphenols content of plant is influenced by multiple factors including species, ripening stage, cultivation and storage conditions. Discrepancies are also likely to occur at the stage of experimental analyses.

According to Uma et al. [2010], the aqueous acetone solution is the most effective solvent for extraction of polyphenols, which has been confirmed by results of this study. The prolongation of extraction time had the most impact in case of methanol solution. The amount of polyphenols extracted decreased. Statistical analysis showed no differences therefore it is more practical to apply shorter time of extraction. 


\section{Determination of total catechins}

The catechin content in dry parsley leaves ranges from 5.36 to $13.82 \mathrm{mg} / 100 \mathrm{~g}$ d.m. depending on the type of solvent and time of extraction. The most effective solvent for catechins turned out to be water, whereas the least effective one $-80 \%$ methanol (Fig. 2). The content of catechins determined after aqueous extraction was over 2 times higher than that assayed after extraction with methanol.

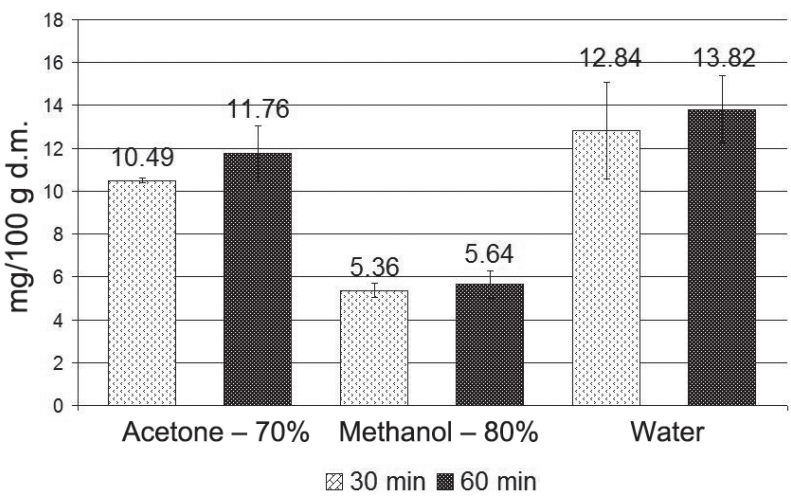

Fig. 2. Total catechin content

The statistical analysis of results for two-agent experiment demonstrated a significant influence of the type of solvent on the quantity of extracted catechins. As for polyphenols, analysis showed no significant effects of extraction time or the correlation between the factors.

According to the Data Base for Flavonoids Content of the USA Department of Agriculture, the content of catechins in dried parsley leaves is very low or none. In a study addressing the impact of different drying methods on losses of flavonoids, Mohd Zainol et al. [2009] demonstrated the loss of catechins during that process to range from 35 to $78 \%$.

Water, which out of the studied extractants was a poor solvent in total polyphenols assay, turned out to be a very good solution for catechins. This was, however, inconsistent with findings of Perva-Uzunalic et al. [2006], who obtained the highest effectiveness of extraction of catechins from green tea when using $70 \%$ acetone, and the lowest one - when using water. Yet, those authors were applying different extraction methods, that might have caused a decrease in catechins content. In turn, Mika et al. [2008] observed that the prolongation of the extraction time resulted in increased effectiveness of catechins extraction. This was not confirmed in our study.

\section{Antioxidative properties}

Figure 3 depicts the percentage capability of the extracts examined to inactivate synthetic DPPH radicals. The most effective in this respect turned out to be $80 \%$ methanolic extracts, followed by $70 \%$ acetone extracts. Differences in that activity between the 30-minute and 60-minute extracts were inconsiderable. Water appeared to be the poorest extractant, for the percentage of radicals inactivated after 30-minute extraction accounted for $79.44 \%$, whereas after 60 -minute extraction for less than $50 \%$. In aqueous extracts, in the natural environment of many biologically-active compounds, some chemical and physical changes were likely to occur that induced the partial degradation of polyphenolic compounds and/or other antioxidants, which in turn resulted in the suppressed activity of these extracts.

It has been statistically proved that there is the influence of the type of solvent and time of extraction on extracts' capability for $\mathrm{DPPH}^{\cdot}$ inactivation. However, the prolongation of extraction time resulted in decrease of activity against DPPH in case of aqueous extracts. For methanolic and acetone extracts differences between shorter and longer extraction were rather smaller and not important. There was no correlation between polyphenols or catechins content and activity

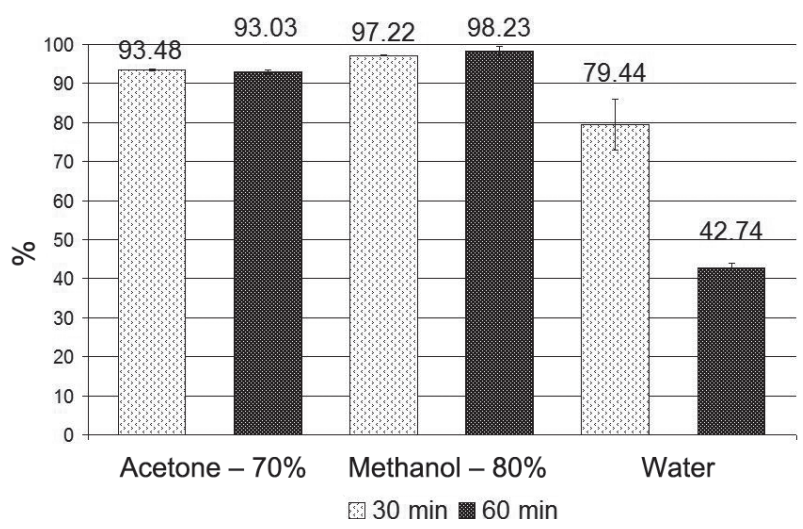

Fig. 3. Capability to inactivate DPPH radicals 
against $\mathrm{DPPH}^{\circ}$. It means that these variables are independent. It seems probable that these compounds did not decide on antiradical activity against DPPH:

The activity of methanolic and aqueous extracts from parsley leaves against $\mathrm{DPPH}^{*}$ was investigated by Wong and Kitts [2006]. They achieved lower results, i.e. $65 \%$ activity in the methanolic extracts and $46 \%$ activity in the aqueous extract. Yet, it should be emphasized that the above-cited authors were applying different concentrations of solvents and different extraction methods. However, a tendency may be observed that in both studies methanol was a better solvent in that method than water. In turn, Woźniak et al. [2009] claim that extracts' activity against $\mathrm{DPPH}^{*}$ depends mainly on the type of solvent applied. The results indicate that different kinds and contents of antioxidant substances which can react with $\mathrm{DPPH}^{\circ}$ are extracted from plants using various extractants. All used solvents were polar, but their polarity was different. The obtained results may be related to the polarity of extractants, which increases in the following order: acetone $>$ methanol $>$ water.

All extracts were characterised by a very high capability for inactivating ABTS cation radicals (Fig. 4). The most effective turned out to be the 60-minute aqueous extraction $(99.43 \%)$ and the least one the 30-minute extraction with methanol $(86.22 \%)$. The values obtained point to high antiradical activity of parsley leaves.

The study demonstrated a statistically significant effect of the type of solvent and extraction time on the antiradical activity as well as correlations between

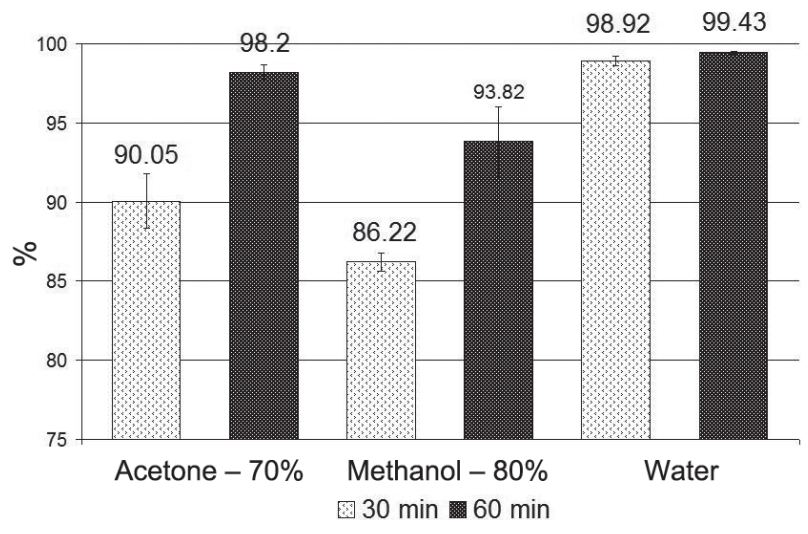

Fig. 4. Capability to inactivate ABTS cation radicals the factors compared. In the case of the acetone and methanol extracts, the prolongation of the extraction time resulted in enhanced chelating capability. The difference noted in the aqueous extract was minimal. A positive, strong correlation was noted between total catechins content and activity against $\mathrm{ABTS}^{+}$. It means that these variables are dependent. The high activity of the extracts may, to some point, be due to the presence of catechins, for the more catechins were extracted the higher the extract's activity was. Cybul and Nowak [2008] report that during $\mathrm{ABTS}^{\cdot+}$ reactions with flavonoids some products may be formed that will be characterized by extremely strong antioxidative effects, reacting more rapidly with the radicals than the native compounds occurring in the extracts. In such cases, results of analyses may be overestimated.

In a research by Yildiz et al. [2008] the best extractant for the assay of the activity against $\mathrm{ABTS}^{\cdot+}$ in lyophilized parsley leaves was $70 \%$ methanol. It was characterized by the highest effectiveness of extraction out of all solvents examined, i.e. aqueous solutions of methanol, ethanol and acetone in concentrations of 100,70 and $50 \%(\mathrm{v} / \mathrm{v})$, and distilled water. The application of $70 \%$ methanol enabled achieving $100 \%$ activity against $\mathrm{ABTS}^{+}$. Our study, however, did not confirm methanol to be the best extractant, but the methanolic extracts also displayed high antiradical activity.

$\mathrm{Fe}(\mathrm{II})$ ions complexation capability determine the ability of components in plant extracts to chelate the free iron ions. Transition metal ions such as iron are important catalysts for the generation of very reactive hydroxyl radicals.

Results of the assays conducted for Fe(II) ions complexation capability are presented in Figure 5. Water turned out to be the best solvent in that reaction, because the aqueous extracts bounded more than $95 \%$ of iron ions. The lowest chelating capability was demonstrated for the acetone extract after 30-minute extraction $(48.36 \%)$.

Analysis demonstrated the influence of the type of solvent on chelating capability to be statistically significant. The effect of extraction time also turned out significant, however, the effects of water and $80 \%$ methanol on ions complexation capability did not differ significantly between one another, but did differ when compared to acetone $70 \%$ used as a solvent. The prolongation of extraction time on ions complexation capability 


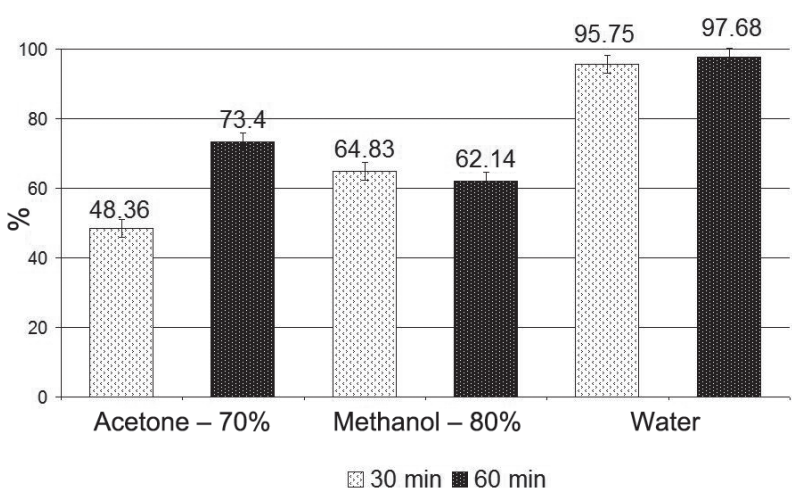

Fig. 5. Fe(II) ions complexation capability

resulted in increase of chelating capacity of acetone extracts. In case of chelating abilities of aqueous and methanolic extracts the differences between shorter and longer were not important. There was no linear correlation between content of polyphenols or catechins and iron ion chelating capacity. On this basis it can be concluded that the variables are independent.

The ability to complex iron ions can vary widely depending on the type of plant. This parameter gives an information whether compounds found in extracts contain potential secondary antioxidants, e.g. flavonoids [Wong et al. 2006]. This study showed that parsley leaves are probably a good source of secondary antioxidants and water is undoubtedly proper extractant.

Yildiz et al. [2008] investigated lyophilized parsley leaves capability for $\mathrm{Fe}^{2+}$ ions complexation in methanolic extracts and achieved complexation effectiveness of $68 \%$. It is consistent with results obtained in the reported experiment. In turn, Wong and Kitts [2006] reported on 54\% chelating capability in methanolic extracts and $47 \%$ chelating capability in aqueous extracts. The lower results may be due to a different chemical composition of the experimental material as well as to losses of antioxidants at the stage of samples preparation or extraction.

The content of carotenoids in the analyzed parsley leaves reached $31.28 \mathrm{mg} / 100 \mathrm{~g}$ d.m. According to Ben-Amotz and Fisher [1998], the mean content of carotenoids in parsley accounts for $45.5 \mathrm{mg} / 100 \mathrm{~g}$ d.m., whereas according to Lisiewska and Kmiecik [1997] for $54.3 \mathrm{mg} / 100 \mathrm{~g}$ d.m. In spite of the fact that in the reported study the experimental material was dried, the differences in carotenoids content were insignificant.
Chen et al. [2007] emphasize that the stability of carotenoid compounds during drying depends on conditions and methods of the process.

In the investigated parsley leaves the content of ascorbic acid accounted for $237.64 \mathrm{mg} / 100 \mathrm{~g}$ d.m. and that of dehydroascorbic acid - for $10.67 \mathrm{mg} / 100 \mathrm{~g} \mathrm{d.m}$. In turn, Lisiewska and Kmiecik [1997] reported ascorbic acid content to reach $1485 \mathrm{mg} / 100 \mathrm{~g}$ d.m. of fresh parsley leaves, whereas data provided in the Slovak Food Composition Data Bank indicate that fresh parsley leaves contain $939 \mathrm{mg}$ ascorbic acid/100 g d.m. Results achieved in our study are considerably lower than those reported elsewhere. Worthy of notice is, however, that ascorbic acid is susceptible to the drying process. Hachuła et al. [2000] report that the loss of vitamin $\mathrm{C}$ depends, to a great extent, on the conditions of plant material drying and storage. Vitamin $\mathrm{C}$ losses are additionally affected by: the presence of metal ions (i.e. copper, iron), light, water activity in the product, presence of oxygen, etc., and during drying may reach even up to $50 \%$ [Sokhansanj and Jayas 2007].

In the reported experiment, the percentage content of dehydroascorbic acid in the total content of ascorbic and dehydroscorbic acids reached $4.3 \%$. It is consistent with findings by Wills et al. [1984], who reported the content of dehydroascorbic acid in parsley to account for less than $5 \%$.

The content of chlorophyll $\mathrm{a}$ and $\mathrm{b}$ in the examined material reached $0.256 \mathrm{mg} / \mathrm{g}$ d.m. According to Lisiewska and Kmiecik [1997], the respective value determined in fresh parsley leaves accounted for $3.93 \mathrm{mg} / \mathrm{g} \mathrm{d} . \mathrm{m}$. Chlorophyll pigments are very susceptible to many factors, including e.g. temperature, $\mathrm{pH}$, oxygen, light or enzymes activity. During processing they are undergoing changes, the extent of which is determined by the character of plant material and processing conditions [Minguez-Mosquera et al. 2002]. It may thus be speculated that in the analyzed dried samples, chlorophyll was subject to degradation.

Chlorophyll a occurs in a significant excess as compared to chlorophyll $\mathrm{b}$. In the studied material, the a:b chlorophyll ratio reached $2.65: 1$, which is close to ideal ratio. In higher plants the preponderance of chlorophyll a, comparatively to chlorophyll b should reach the values of about $3: 1$ or even $3: 2$. This is the indicator of the degree of lighting assuring an adequate plant development [Olteanu et al. 2008]. 


\section{CONCLUSIONS}

1. Parsley leaves are a rich source of antioxidants.

2. The best extractant for polyphenols extraction turned out to be aqueous acetone $70 \%$, whereas for catechins extraction - distilled water.

3. All extracts examined displayed the antioxidative activity. Distilled water was the best solvent in the method of assaying the activity against $\mathrm{ABTS}^{++}$ and $\mathrm{Fe}^{2+}$ ions chelating capability, whereas methanol and acetone turned out to be the less effective in this respect. Opposite results were observed in the case of determining the activity against $\mathrm{DPPH}^{\cdot}-$ methanol was the best extractant, whereas water was the least effective.

4. In some cases, the prolongation of the extraction enhanced antiradical activity. However, a longer time increases the cost of analysis. In cases where there was no much difference in extracted amounts of polyphenols, catechins or in antioxidative properties, it is more economical to apply shorter time of extraction.

5. Apart from polyphenolic compounds, the extracts examined contained other biologically-active compounds with beneficial effects on a human body. High contents were determined for vitamin C $(248.31 \mathrm{mg} / 100 \mathrm{~g}$ d.m. and natural pigments: carotenoids $(31.28 \mathrm{mg} / 100 \mathrm{~d} . \mathrm{m}$.) and chlorophyll $(0.185 \mathrm{mg} / \mathrm{g}$ d.m. $)$.

6. Further studies need to be carried out in order to determine what are the major contributors to the high antioxidant activity of different parsley leaf extracts.

\section{REFERENCES}

Al-Mamary M., 2002. Antioxidant activity of commonly consumed vegetables in Yemen. Malays J. Nutr. 8, 179-189 .

Ben-Amotz A., Fisher R., 1998. Analysis of carotenoids with emphasis on 9 -cis- $\beta$-carotene in vegetables and fruits commonly consumed in Israel. Food Chem. 4, 515-520.

Chen J., Tai C., Chen B., 2007. Effects of different drying treatments on the stability of carotenoids in Taiwanese mango (Mangifera indica L.). Food Chem. 100, 1005-1010.

Cybul M., Nowak R., 2008. Przegląd metod stosowanych w analizie właściwości antyoksydacyjnych wyciągów roślinnych [Review of the methods applied to measuring of antioxidant activity of plant extracts]. Herba Pol. 1, 69-78 [in Polish].

Dragovic-Uzelac V., Pospisil J., Levaj B., Delonga K., 2005. The study of phenolic profiles of raw apricots and apples and their purees by HPLC for the evaluation of apricot nectars and jam authenticity. Food Chem. 91, 373-383.

Dżugan M., 2006. Czynniki wpływające na stabilność zielonych barwników roślin [Factors affecting the stability of the green vegetable dyes]. Zesz. Nauk. PTG 7, 27-33 [in Polish].

Ferruzzi M.G., Blakeslee J., 2007. Digestion, absorption, and cancer preventative activity of dietary chlorophyll derivatives. Nutr. Res. 27, 1-12.

Gao M., Liu C.-Z., 2005. Comparison of techniques for the extraction of flavonoids from cultured cells of Saussurea medusa Maxim. World J. Microbiol. Biotechnol. 21, 1461-1463.

Hachuła U., Zawisza B., Winkler W., 2000. Zastosowanie metody chromatograficzno-spektrofotometrycznej do analitycznej kontroli kwasu L-askorbinowego w materiale farmaceutycznym i roślinnym [Application of the chromatographic-spectrophotometric method for analytical control of L-ascorbic acid in pharmaceutical and plant material]. Rocz. PZH 1, 71-78 [in Polish].

Kleszczewska E., 2007. Biologiczne znaczenie witaminy C ze szczególnym uwzględnieniem jej znaczenia w metabolizmie skóry [The biological importance of vitamin C with particular emphasis on its role in the metabolism of the skin]. Pol. Merk. Lek. 23, 138, 462-465 [in Polish].

Koffi E., Sea T., Dodehe Y., Soro S., 2010. Effect of solvent type on extraction of polyphenols from twenty three Ivorian plants. J. Anim. Plant Sci. 5, 550-558.

Lai L.S., Chou S.T., Chao W.W., 2001. Studies on the antioxidative activities of Hsian-tsao (Mesona procumbens Hemsl) leaf gum. J. Agric. Food Chem. 49, 963-968.

Lisiewska Z., Kmiecik W., 1997. Effect of freezing and storage on quality factors in Hamburg and leafy parsley. Food Chem. 4, 633-637.

Mika M., Wikiera A., Żyła K., 2008. Wpływ czasu i temperatury ekstrakcji na zawartość katechin w wodnych ekstraktach herbaty białej [Effect of extraction time and temperature on the content of catechins in white tea water extracts]. Żywn. Nauka Technol. Jakość 6, 88-94 [in Polish].

Minguez-Mosquera M.B., Gandul-Rojas B., Gallardo-Guerrero L., Jaren-Galan M., 2002. Chlorophylls. In: Methods of analysis for functional foods and nutraceuticals. Ed. W.J. Hurst. CRC Press New York, 159-187.

Mohd Zainol M.K., Abdul-Hamid A., Abu Bakar F., Pak Dek S., 2009. Effect of different drying methods on the 
degradation of selected flavonoids in Centella asiatica. Int. Food Res. J. 16, 531-537.

Mosiewicz R., 2002. Karotenoidy - schwytane promienie słoneczne [Carotenoids - the sunlight captured]. Przem. Ferm. Owoc. Warz. 4, 2-3 [in Polish].

Olteanu Z., Zamfirache M., Oprica L., Truta E., 2008. Comparative study of behaviour of some biochemical parameters in different phenophases of seabuckthorn cultivars. Analele Stiintifice Ale Universitatii "Alexandru Ioan Cuza” Din Iasi Sec. II A. Genetica Si Biologie Moleculara 4, 47-54.

Perva-Uzunalic A., Skerget M., Knez Z., Weinreich B., Otto F., Grucher S., 2006. Extraction of active ingredients from green tea (Camellia sinensis). Extraction efficiency of major catechins and caffeine. Food Chem. 4, 597-605.

PN-EN 14130:2004. Artykuły żywnościowe. Oznaczanie witaminy C metodą HPLC [Foodstuffs. Determination of vitamin $\mathrm{C}$ content by HPLC]. Polski Komitet Normalizacyjny Warszawa [in Polish].

Re R., Pellegrini N., Pannala A., Yang M., Rice-Evans C., 1999. Antioxidant activity applying an improved ABTS radical cation decolorization assay. Free Rad. Biol. Med. 9, 1231-1237.

Rosicka-Kaczmarek J., 2004. Polifenole jako naturalne antyoksydanty w żywności [Polyphenols as natural antioxidants in food]. Przegl. Piek. Cuk. 6, 12-16 [in Polish].

Rząca M., Witrowa-Rajchert D., 2009. Zmiany aktywności przeciwrodnikowej i zawartości polifenoli w suszu jabłkowym uzyskanym przy wykorzystaniu promieniowania podczerwonego [Changes in radical scavenging and in content of polyphenols in the dried apples produced using infrared radiation]. Żywn. Nauka Technol. Jakość 1, 99-108 [in Polish].

Sikora E., Cieślik E., Topolska K., 2008. The sources of natural antioxidants. Acta Sci. Pol., Technol. Aliment. 1, 5-17.

Singleton V.L., Rossi J.A., 1965. Colorimetry of total phenolics with phosphomolybolic - phosphotungstic acid reagents. Am. J. Enol. Viticult. 16, 144-158.

Slovak Online Food Composition Database, 2010. [online], http://www.pbd-online.sk/ (access: 14.06.2010).

Sokhansanj S., Jayas D.S., 2007. Drying of foodstuffs. In: Handbook of industrial drying. Ed. A.S. Mujumdar. CRC Press, New York, 521-546.

Song T.T., Hendrich S., Murphy P.A., 1999. Estrogenic activity of glycitein, a soy isoflavone. J. Agric. Food Chem. 47, 1607-1610.
Sultana B., Anwar F., Ashraf M., 2009. Effect of extraction solvent/technique on the antioxidant activity of selected medicinal plant extracts. Molecules 14, 2167-2180.

Swain T., Hillis W., 1959. The phenolic constituents of Prunas domestica. 1. The quantitative analysis of phenolic constituents. J. Sci. Food Agric. 10, 63-68.

Szpetnar M., Pasternak K., 2003. Wpływ karotenoidów na zdrowie człowieka [Effect of carotenoids on human health]. Herba Pol. 3-4, 427-435 [in Polish].

Sztangret J., Korzeniowska A., Niemirowicz-Szczyt K., 2001. Ocena plonowania oraz zawartości suchej masy i związków karotenoidowych w nowych mieszańcach dyni olbrzymiej (Cucurbita maxima Duch.) [Assessment of yielding and content of dry matter and carotenoids in new hybrids of winter squash (Cucurbita maxima Duch.)]. Folia Hort. 13/1A, 37-43 [in Polish].

Uma D.B., Ho C.W., Wan Aida W.M., 2010. Optimization of extraction parameters of total phenolic compounds From henna (Lawsonia inermis) leaves. Sains Malays 39, 119-128.

USDA Database for the Flavonoid Content of Selected Foods, 2003. [online], http://www.nal.usda.gov/fnic/ foodcomp/Data/Flav/flav.pdf (access: 12.06.2010).

Wills R.B.H., Wimalasiri P., Greenfield H., 1984. Dehydroascorbic acid levels in fresh fruit and vegetables in relation to total vitamin C activity. J. Agric. Food Chem. 32, 836-838.

Wong P.Y.Y., Kitts D.D., 2006. Studies on the dual antioxidant and antibacterial properties of parsley (Petroselinum crispum) and cilantro (Coriandrum sativum) extracts. Food Chem. 97, 505-515.

Wong S.P., Leong L.P., Koh J.H.W., 2006. Antioxidant activities of aqueous extracts of selected plants. Food Chem. 99, 775-783.

Woźniak M., Ostrowska K., Szymański Ł., Wybieralska K., Zieliński R., 2009. Aktywność przeciwrodnikowa ekstraktów szałwi i rozmarynu [Antiradical activity of sage and rosemary extracts]. Żywn. Nauka Technol. Jakość 4, 133-141 [in Polish].

Yildiz L., Başkan K.S., Tütem S., Apak R., 2008. Combined HPLC-CUPRAC (cupric ion reducing antioxidant capacity) assay of parsley, celery leaves, and nettle. Talanta 77, 304-313.

Zeno G., 2007. Liquid Chlorophyll - nowość w odżywianiu [Liquid Chlorophyll - innovation in nutrition]. Nutr. Health 1, 1-12 [in Polish]. 


\section{OPTYMALIZACJA WARUNKÓW EKSTRAKCJI NIEKTÓRYCH ZWIĄZKÓW POLIFENOLOWYCH Z LIŚCI PIETRUSZKI (PETROSELINUM CRISPUM)}

\section{STRESZCZENIE}

Wstęp. Natka pietruszki jest bogatym źródłem naturalnych antyoksydantów, które pełnią wiele funkcji w organizmie człowieka i zapobiegają procesom utleniania w żywności. Celem pracy było zbadanie wpływu różnych rozpuszczalników i czasów ekstrakcji na zawartość naturalnych antyoksydantów w liściach pietruszki. Znajomość właściwości ekstrahowanych składników oraz ich interakcji daje możliwość osiągnięcia dużej efektywności ekstrakcji związków bioaktywnych.

Materiał i metodyka. Trzy różne rozpuszczalniki (roztwór wodny acetonu 70\%, roztwór wodny metanolu $80 \%$ i woda destylowana) oraz różne czasy ekstrakcji (30 i 60 min) były użyte do określenia efektywności ekstrakcji polifenoli i katechin, aktywności przeciwutleniającej wobec wolnych rodników DPPH i ABTS oraz zdolności ekstraktów do chelatowania jonów $\mathrm{Fe}^{2+} \mathrm{w}$ suszonych liściach pietruszki.

Wyniki i wnioski. Najlepszym ekstrahentem do ekstrakcji polifenoli ogółem był roztwór wodny acetonu o stężeniu 70\%, a do ekstrakcji katechin - woda. Wszystkie ekstrakty wykazywały właściwości przeciwutleniające, ale woda była najlepszym rozpuszczalnikiem w metodzie określania aktywności wobec rodnika ABTS i chelatowania jonów żelaza, natomiast najmniej efektywny był metanol o stężeniu 80\%. Określając aktywności ekstraktów wobec rodników DPPH, zaobserwowano tendencję odwrotną. W niektórych przypadkach stwierdzono wzrost lub zmniejszenie aktywności antyrodnikowej wraz z wydłużeniem czasu ekstrakcji. Dodatkowo w liściach pietruszki zidentyfikowano ważne, biologicznie aktywne związki takie, jak witamina C (248,31 mg/100 g suchej masy), karotenoidy (31,28 mg/100 g suchej masy), chlorofil (0,185 mg/g suchej masy).

Słowa kluczowe: efektywność ekstrakcji, właściwości przeciwutleniające, przeciwutleniacze naturalne

For citation - Do cytowania

Kuźma P., Drużyńska B., Obiedziński M., 2014. Optimization of extraction conditions of some polyphenolic compounds from parsley leaves (Petroselinum crispum). Acta Sci. Pol., Technol. Aliment. 13(2), 145-154. 